\title{
Differences in host-infection patterns of clinostomatids (Clinostomatidae) in human disturbed aquatic ecosystems against undisturbed lake
}

\section{Paul Chinedu Echi* and Mary Omeagu Ojebe}

Michael Okpara University of Agriculture, Umudike, Nigeria. *Email: paul_echi@yahoo.com.

\begin{abstract}
Scarcely use of Opi Lake for many years (1995-2007) due to road cut to its site by erosion during which parasite survey of its major fish composition was carried out established host specificity disparity especially when compared with entirely human disturbed Oguta Lake and Anambra River Basin in Southeast, Nigeria. The infection prevalence had dispersed infection in mainly skin musculature micro-habitat in encysted forms in the later reservoirs. Conversely, the parasites occupied more host micro-habitats of eye, skin and buccal cavity with high rate of excysted forms in the former reservoir. The record of mainly encysted forms in the latter reservoirs is indicative of immune resistance host-parasite relationship. Also, human disturbance which has complimentary environmental influence on both parasite and host upsets parasitehost location strategies in aquatic communities within human vicinities where the reservoirs are used for numerous domestic chores. To the best of our knowledge, hitherto the latter had little or no clinostomatids parasites report.
\end{abstract}

Keywords: Clinostomatids; Fallow; Anthropogenic disturbance; Environment.

\section{Introduction}

Although in Anambra River Basin the fish composition parasites have been relatively studied unlike in Oguta Lake where the parasites that associate with the major fish composition maintain little or no knowledge. However, hitherto, both aquatic ecosystems maintain scarce or no information in respect of clinostomatid infections. It is a reputable verity that many African aquatic faunal biodiversity are bereft of information on their parasites, therefore data deficient (Echi and Ezenwaji,
2009). Conversely, many boost of comprehensive studies (Khalil, 1961; Paperna, 1980; Hare and Carter, 1986; Chapman and Chapman, 1993b; Ezenwaji 2002; Echi and Ezenwaji 2009). Although clinostomatids are well discussed in literatures, information on their host specificity is inadequate (Chung et al., 1995; Tiewchaloen, 1999; Dias et al., 2003). Therefore, comparison of their infection patterns in aquatic ecosystems with different attributes has become necessary in an attempt to revisit the common inference in literatures that 
Clinostomum spp generally has little host specificity.

The genus Clinostomum (Leidy, 1856) is a digenetic trematode with broad spread that uses molluscs and fish as first and second intermediate hosts respectively whereas bird eating fish serve as definitive host (Dias et al. 2003). The adult trematode of Clinostomum are attached to the upper and lower jaws of cattle egrets, herons etc. Species of Clinostomum have been described from freshwater fish in Nigeria and many parts of the world. One of the open up studies on Clinostomum species was by Ukoli (1966b), which described Clinostomum tilapiae in the intestine of Oreochromis niloticus and Sarotherodon galilaeus in the River Niger. Other species of Clinostomum, e.g. Clinostomum complanatum has been recorded in the fish of River Niger (Ukoli, 1966a), Clinostomum spp were found to be common in Tilapia spp while those of Euclinostomum spp were recovered mainly from the osteoglossid Heterotis niloticus. Clinostomum complanatum and Clinostomum tilapiae have been recovered from African continent with Euclinostomum heterostomum being cosmopolitan (Malek and Mobedi, 2001). The metacercariae have penchant for the mesenteries of blood capillaries which contains the nutrients they feed on through passive, active or facilitated diffusion in these micor-habitats, indicates higher prevalence and abundance of the parasites around them and relative larger morphometric body length of C. complanatum in a concomitant infection was due to more influx of nutrients into their larger surfaces than the other two clinostomatids species (Echi et al., 2009a). The higher prevalence and abundance of parasites in the area under the mouth to behind the operculum are probably due to the presence of blood, which Clinostomum complanatum feed on (Malek and Mobedi, 2001). Metacercariae may affect growth and survival, or disfigure fish so that they lose their market value as a food or ornamental product (Paperna, 1991). Some metacercariae in fisheries and aquaculture products are a source for infections in humans and domestic animals (Deardoff and Overstreet, 1991). Pathology of clinostomatids infections becomes undesirably severe in a concomitant infection of more than two species. This apart from intermittent deaths reduces fish tegument value and patho-physiology of visceral organs that provide micro-habitats for them in their fish hosts by the excysted metacercariae. Therefore, the chance to have most reproductive success than other species depends on availability of more excysted forms in each host (Echi et al., 2012).

Due to paucity information on the host specificity pattern of clinostomatids infections, we engendered this study to provide situations in some aquatic ecosystems in Nigeria to determine human disturbance in the host specificity of clinostomatids. In addition, to present clinostomatids infection of fish of Oguta Lake and Anambra Rvier Basin at Otuocha sampling location.

\section{Materials and methods}

Oguta Lake $\left(05^{\circ} 42^{\prime} 24^{\prime \prime} \mathrm{N}\right.$ and $06^{\circ} 47^{\prime} 33^{\prime \prime}$ E), Opi Lake (06 $45^{\prime} 0^{\prime \prime} \mathrm{N}$ $06^{\circ} 45^{\prime} 28^{\prime \prime} \mathrm{N} \quad$ and $07^{\circ} 29^{\prime} 28^{\prime \prime} \mathrm{E}$ $07^{\circ} 29^{\prime} 35^{\prime}$ ' E), and Anambra River Basin $\left(06^{\circ} 21^{\prime} 29.2^{\prime \prime} \mathrm{N}\right.$ and $\left.06^{\circ} 51^{\prime} 21.99^{\prime \prime} \mathrm{E}\right)$ freshly and frequently caught fish samples were studied consecutively for 12 months (December 2014 - November 2015) while Opi Lake (November 2007 - October 2008). Examination of fish for parasites and procedures for treatment, fixation and preservation of recovered parasites maintained the standard methods in (Ash and Orihel 1987; Arthur and Albert, 1994). The parasites were identified using details in Ukoli (1966a). Infection statistics of Bush et al. (1997) was used for the determination of prevalence, abundance and mean intensity.

\section{Results}

The three aquatic bodies had C. gariepinus and $T$. zillii as the most common occurring fish. However, in Anambra River basin and Oguta Lake 
Brachysynodontis batensoda and Synodontis clarias were the only clinostomatids infected hosts while in Opi Lake the cichlids - Tilapia guinensis, Sarotherodon melanotheron and Tilapia zillii were the only affected fish hosts with the highest clinostomatids infection recorded in $T$. zillii. No clinostomatids parasites were recovered from cichlids in Anambra River basin and Oguta Lake. Also, there was no record of infection of $C$. gariepinus in all the three aquatic ecosystems. The results obtained from Opi Lake had been reported (Echi et al., 2009a; Echi et al., 2009b; Echi et al., 2012).

Total of $63 \mathrm{~B}$. batensoda procured from fishers at Anambra River Basin' (December 2014 - November 2015) were infected with 187 clinostomatids (Clinostomum complanatum 79, Euclinostomum heterostomum 62, and Clinostomum tilapiae 46) and 45 S. clarias were infected with 166 (Clinostomum complanatum 86, Euclinostomum heterostomum 29, and Clinostomum tilapiae 51).

All the 63 B. batensoda (prevalence 100\%, mean intensity 2.96) and $45 \mathrm{~S}$. clarias (prevalence 100\%, mean intensity 3.68) studied were infected. The rate of infection was higher during dry season months than rainy season months as well as larger fish than smaller hosts. There was only one micro-habitat of skin musculature in entirely encysted forms. Out of 210 B. batensoda and 314 S. clarias collected from fishers at Oguta Lake clinostomatids had dispersed infection. For instance, 184 B. batensoda hosts (prevalence 87.61\%, mean intensity 1.39 , and abundance 1.21 ) had 256 clinostomatids while 215 S. clarias hosts (prevalence 68.47\%, mean intensity 1.47, and abundance 1.01) had 318 clinostomatids (Table 1).

Table 1. Clinostomatids infection spectrum in Anambra River and Oguta Lake.

\begin{tabular}{|c|c|c|c|c|c|c|}
\hline Fish host & Parasites recovered & I. H. & I. P. & $\mathbf{P}(\%)$ & M. I. & Ab. \\
\hline \multicolumn{7}{|c|}{ Anambra River Basin } \\
\hline \multirow{3}{*}{$\begin{array}{c}\text { B. batensoda } \\
n=63\end{array}$} & Clinostomum complanatum & 28 & 79 & 44.4 & 2.8 & 1.2 \\
\hline & E. heterostomum & 16 & 62 & 25.3 & 3.8 & 0.9 \\
\hline & Clinostomum tilapiae & 19 & 46 & 30.1 & 2.4 & 0.7 \\
\hline \multirow{3}{*}{$\begin{array}{l}\text { S. clarias } \\
\mathrm{n}=45\end{array}$} & Clinostomum complanatum & 8 & 85 & 17.7 & 10.6 & 1.8 \\
\hline & E. heterostomum & 23 & 29 & 51.1 & 1.2 & 0.6 \\
\hline & Clinostomum tilapiae & 14 & 51 & 31.1 & 3.6 & 1.1 \\
\hline \multicolumn{7}{|l|}{ Oguta Lake } \\
\hline \multirow{3}{*}{$\begin{array}{c}\text { S. clarias } \\
\mathrm{n}=314\end{array}$} & Clinostomum complanatum & 89 & 231 & 28.3 & 1.7 & 0.7 \\
\hline & E. heterostomum & 116 & 236 & 36.9 & 1.0 & 0.2 \\
\hline & Clinostomum tilapiae & 113 & 246 & 35.9 & 1.1 & 0.7 \\
\hline \multirow{3}{*}{$\begin{array}{c}\text { B. batensoda } \\
\mathrm{n}=210\end{array}$} & Clinostomum complanatum & 86 & 168 & 40.7 & 1.9 & 0.8 \\
\hline & E. heterostomum & 58 & 176 & 27.6 & 3.0 & 0.8 \\
\hline & Clinostomum tilapiae & 40 & 178 & 19.0 & 4.4 & 0.8 \\
\hline
\end{tabular}

Key: I. H. = Individual hosts; I. P. = Individual parasites; P = Prevalence; M. I. = Mean intensity; Ab. = Abundance.

Prevalence by month occurred higher in dry season periods $\geq 10.1 \%$ synonymous with habitat contraction than wet periods except $B$. batensoda infection in May (13.3\%) and July (13.8\%) in Anambra River and Oguta Lake respectively (Tables 2 and 3). There is no significant difference between prevalence of the parasites in Anambra River Basin whereas there is significant difference between prevalence of the parasites in Anambra River Basin and Oguta Lake and the two habitats with Opi Lake ( $p<0.05)$. 
The parasites occupied more host microhabitats of eye, skin and buccal cavity in Opi Lake unlike the other two aquatic ecosystems where only the host microhabitat of skin musculature harboured the parasites in encysted forms.

Table 2. Seasonal infection of clinostomatids in the Anambra River.

\begin{tabular}{|l|c|c|c|c|c|c|c|c|}
\hline \multirow{2}{*}{ Month } & \multicolumn{4}{|c|}{$\begin{array}{c}\text { Number of B. batensoda/monthly } \\
\text { prevalence }\end{array}$} & \multicolumn{4}{c|}{$\begin{array}{c}\text { Number of S. clarias/monthly } \\
\text { prevalence }\end{array}$} \\
\cline { 2 - 9 } & & C.c. & E.h. & C.t. & & C.c. & E.h. & C.t. \\
\hline January & $6(9.5)$ & 7 & 3 & 3 & $3(6.6)$ & 6 & 2 & 5 \\
\hline February & $6(9.5)$ & 10 & 6 & 6 & $4(8.8)$ & 9 & 2 & 4 \\
\hline March & $4(6.3)$ & 8 & 4 & 5 & $3(6.6)$ & 5 & 3 & 3 \\
\hline April & $3(4.7)$ & 6 & 6 & 2 & $2(4.4)$ & 4 & 2 & 2 \\
\hline May & $4(6.3)$ & 5 & 8 & 2 & $6(13.3)$ & 6 & 2 & 6 \\
\hline June & $6(9.5)$ & 5 & 6 & 4 & $3(6.6)$ & 6 & 3 & 4 \\
\hline July & $5(7.9)$ & 4 & 5 & 7 & $4(8.8)$ & 8 & 2 & 2 \\
\hline August & $6(9.5)$ & 7 & 5 & 3 & $2(4.4)$ & 7 & 3 & 5 \\
\hline September & $4(6.3)$ & 7 & 3 & 3 & $2(4.4)$ & 9 & 2 & 4 \\
\hline October & $5(7.9)$ & 6 & 4 & 3 & $16(13.3)$ & 4 & 3 & 7 \\
\hline November & $6(9.5)$ & 8 & 6 & 5 & $4(8.8)$ & 12 & 2 & 5 \\
\hline December & $8(12.6)$ & 6 & 6 & 3 & $6(13.3)$ & 9 & 3 & 4 \\
\hline
\end{tabular}

Key: C.c. $=$ C. complanatum; E.h. = Euclinostomum heterostomum; C.t $=$ C. tilapiae .

Table 3. Seasonal infection of clinostomatids in the Oguta Lake.

\begin{tabular}{|l|c|c|c|c|c|c|c|c|}
\hline \multirow{3}{*}{ Month } & \multicolumn{3}{|c|}{$\begin{array}{c}\text { Number of B. batensoda/monthly } \\
\text { prevalence }\end{array}$} & \multicolumn{4}{c|}{$\begin{array}{c}\text { Number of S. clarias/monthly } \\
\text { prevalence }\end{array}$} \\
\cline { 2 - 10 } & & C.c. & E.h. & C.t. & & C.c. & E.h. & C.t. \\
\hline January & $16(7.4)$ & 16 & 20 & 24 & $12(5.7)$ & 12 & 12 & 12 \\
\hline February & $24(11.1)$ & 24 & 24 & 24 & $27(12.8)$ & 27 & 27 & 30 \\
\hline March & $15(6.9)$ & 15 & 15 & 15 & $8(3.8)$ & 8 & 8 & 8 \\
\hline April & $16(7.4)$ & 18 & 19 & 20 & $9(4.2)$ & 9 & 5 & 7 \\
\hline May & $16(7.4)$ & 17 & 18 & 20 & $8(3.8)$ & 8 & 8 & 8 \\
\hline June & $15(6.9)$ & 16 & 16 & 16 & $8(3.8)$ & 8 & 8 & 8 \\
\hline July & $15(6.9)$ & 20 & 15 & 16 & $29(13.8)$ & 9 & 14 & 9 \\
\hline August & $15(6.9)$ & 16 & 18 & 18 & $7(3.3)$ & 7 & 7 & 7 \\
\hline September & $18(8.3)$ & 19 & 20 & 22 & $16(7.6)$ & 16 & 17 & 16 \\
\hline October & $20(9.3)$ & 24 & 20 & 26 & $19(9.0)$ & 19 & 24 & 26 \\
\hline November & $22(10.2)$ & 26 & 24 & 23 & $16(7.6)$ & 18 & 17 & 19 \\
\hline December & $23(10.6)$ & 20 & 26 & 24 & $25(11.9)$ & 27 & 29 & 28 \\
\hline
\end{tabular}

Key: C.c. $=$ C. complanatum; E.h. = Euclinostomum heterostomum; C.t = C. tilapiae.

In Anambra River, C. complanatum had the highest prevalence in $B$. batensoda (44.4\%) while $E$. heterostomum had the least prevalence (25.3\%). In the other host, S. clarias E. heterostomum had the highest prevalence (51.1\%) wereas C. complanatum had the least prevalence (17.7\%). In Oguta Lake, the trend remains constant except difference in the prevalence percentages of $36.9 \%$ in S. clarias and $40.7 \%$ in B. batensoda, respectively (Table 1).

\section{Discussion}

Although, Clinostomum spp are generally have little host specificity (Chung et al., 1995; Tiewchaloen, 1999; Dias et al., 
2003), they appear more attracted to Cichlids than other fish species which together form the major fish composition of Opi Lake. The Lake remained relatively undisturbed many years (1995-2007) due to inaccessibility as a result of road cut by endemic erosion disaster in the Southeastern parts of Nigeria. This inadvertently enabled innate manifestation of host attraction in this natural ecosystem conditions bereft of anthropologic influence during these years of fallow (Echi, 2009).

Encysted forms in B. batensoda and S. clarias in Oguta Lake and Anambra River are suggestive of high host immune resistance to the infection. Interestingly, in Indian subcontinent, $C$. complanatum occur readily in encysted metacercarial form in the host Channa punctatus (Siddiqui and Nizami, 1982; Shareef and Abidi, 2012). It has been well elaborated that perhaps, immunological resistance makes these encysted forms cause little or no harm to the fish intermediate hosts (Echi et al., 2012). Therefore, these cichlids possess low immune resistance to clinostomatid infections. Consequently, these cichlids were more susceptible to clinostomatids infections with high mortality rate, exophthalmus and severe skin damage (Echi, 2009).

Stressful conditions block the defence mechanisms and may cause a sudden outbreak of disease. Sudden stresses affecting the adrenal gland, which produces adrenalin and noradrenalin, can cause nervousness, hyper motility, and hyperventilation and increase the frequency of the heart conditions. In extreme cases, these minute changes can lead to the rapid death of the fish, due to shock and rapid energy mobilization as a consequence of which the fish loses its energy balance. On the other hand, even small stresses which permanently affect the organism increase the corticoid hormone production of the adrenal gland. The corticoids block the protective mechanisms of the fish phagocytosis and immune responsiveness, allowing any living agent to more easily penetrate the body and cause damage (Woo, 1995).
However, while a number of anthropogenetic pollutants (such as dioxins) are known to cause immunosuppressant of some immune variables others can, at certain exposure levels, lead to enhancement of some immune variables (Paul et al., 1995). Parasites are also good indicators of environmental contaminants and stress (Mackenzie et al., 1995). The human disturbance at Oguta Lake is severed by an attempt to dredge Orashi River which now flows into Oguta Lake and both are constantly fished and used for other purposes. In human disturbed aquatic ecosystems, the metacercariae of Clinostomum spp follow fastidious fish hosts to the substratum and other less human disturbed sites to evade any consequence. Any factor affecting free living aquatic organisms affects complimentarily the parasites community therein (Echi and Ezenwaji, 2009).

These aquatic ecosystems encounter different anthropogenic influences. Whilst Oguta Lake and Anambra River Basin are under human disturbances along their banks due to constant use and presence of human habitations in their vicinities, Opi Lake is entirely in the jungle with strict customary abhorrence of its use by the locals and had fallowed for thirteen years (1985-2015) covering the period of this study sequel to road cut by erosion to its site. Human disturbances, especially some undesirable activities of those that live along the banks of aquatic ecosystems can induce stress to aquatic organisms (Echi, 2005). Stress can permanently affect the organism by increasing the corticoid hormone production of the adrenal gland. The corticoids block the protective mechanisms of the fish phagocytosis and immune responsiveness, thereby making the fish prone to parasitic infections (Woo, 1995).

\section{Conclusion}

The present study supports
clinostomatids host specificity in undisturbed aquatic ecosystem. In addition, clinostomatids metacercariae infect fastidious fish host that respond to human 
disturbance to evade any consequences by moving to undisturbed and or favourable sites with their complimentary clinostomatids metacercariae parasites.

\section{References}

Chapman, I. J.; Chapman, C. A. Fish populations in tropical floodplain pools. A reevaluation of Holden's data on the River Sokoto. Ecol. Freshw., v. 2, no. 1, p. 23-30, 1993. http://dx.doi.org/10.1111/j.16000633.1993.tb00013.x

Chung, D.-I. I.; Kong, H. H.; Moon, C. H. Demonstration of the second intermediate hosts of Clinostomum complanatum in Korea. Korean J. of Parasitol., v. 33, p. 305-312, 1995. http://dx.doi.org/10.3347/kjp.1995.33.4.305

Deardorff, T. L.; Overstreet, R. M. Seafoodtransmitted zoonoses in the United States: the fishes, and the worms. In: Ward, D. R.; Hackeney, C. (Eds.). Microbiology of marine food products. New York: Van Reinold, 1991.

Dias, M. L. G. G.; Eiras, J. C.; Machado, M. H.; Souza, G. T. R.; Pavanelli, G. C. The life cycle of Clinostomum complanatum Rudolphi, 1814 (Digenea, Clinostomidae) on the flood plain of the high Paraná River. Brazil. Parasitol. Res., v. 89, p. 506-508, 2003. http://dx.doi.org/10.1007/s00436-002-0796-z

Echi, P. C.; Ezenwaji, H. M. G. The parasites fauna of characids' (Osteichthyes: Characidae) Anambra River, Nigeria. Afr. J. of Ecol., v. 48, p. 1-4, 2010. http://dx.doi.org/ 10.1111/j.13652028.2009.01030.x

Echi, P. C. Ecology, morphometrics of helminthparasites and histopathological studies of fishes of Opi Lake, Enugu State, Nigeria. Enugu: University of Nigeria, 2009. (Ph. D. Thesis).

Echi, P. C.; Eyo, J. E.; Okafor, F. C.; Onyishi, G. C.; Ivoke, N. First record of co-infection of three clinostomatid parasites in cichlids (Osteichthyes: Cichlidae) in a tropical freshwater lake. Iranian J. Publ. Health, v. 41, no. 7, p. 86-90, 2012. Available from: $<$ http://ijph.tums.ac.ir/index.php/ijph/article/ download/2551/2531>. Accessed in: Oct. 15, 2015.

Ezenwaji, H. M. G. The biology of Clarias ebriensis Pellegrin, 1920 (Osteichthyes: Clariidae) in an African rainforest river basin. Fisheries Res., v. 54, no. 2, p. 235-252, 2002. http://dx.doi.org/10.1016/S0165-7836(00)00291-5
Hare, L.; Carter, J. C. H. The benthos of a natural West African lake, with emphasison the diet, migrations, lunar and seasonal periodicities of the Chaoborus populations (Diptera: Chaoboridae). Freswater Bio., v. 16, p. 759780, 1986. http://dx.doi.org/10.1111/j.13652427.1986.tb01016.x

Khalil, L. F.; Thurston, J. P. Studies on the helminth parasites of freshwater fishes of Uganda including description of two new species of digeneans. Revue de Zool. et Botanie Afri., v. 87, p. 231-248, 1973.

Mackenzie, K.; Williams, H. H.; Williams, B.; McVicar, A. H; Siddall, R. Parasites as indicators of water quality and the potential use of helminth transmission in marine pollution studies. Advanced in Parasitol., v. 35, p. 85144, 1995.

Malek, M.; Mobedi, I. Occurrence of Clinostomum complanatum (Rudolphi, 1819) (Digenea: Clinostomatidae) in Capoeta capoeta gracilis (Osteichthys: Cyprinidae) from Shroud River, Iran. Iranian J. Publ. Health, v. 30, no. 3/4, p. 95-98, 2001. Available from: $<$ http://ijph.tums.ac.ir/index.php/ijph/article/do wnload/1649/1630>. Accessed in: Oct. 15, 2015.

Paul, I.; Mandal, C.; Mandal, C. Effect of environmental pollutants on the C-reactive protein of a freshwater carp - Catta catta. Dev. and Comp. Immunol., v. 22, p. 519-532, 1998. http://dx.doi.org/10.1016/S0145305X(98)00031-7

Paperna, I. Parasites, infection and diseases of fish in Africa. Rome: FAO. 1980. (CIFA Technical Paper).

Paperna, I. Diseases caused by parasites in the aquaculture of warm fish. Annual Review of Fish Diseases, v. 1, p. 155-194, 1991.

Tiewchaloern, S.; Udomkijdecha, S.; Suvouttho, S.; Chunchamsri, K.; Waikagul, J. Clinostomum trematode from human eye. Southeast Asian J. Trop. Med. Public Health, v. 30, no. 2, p. 382384, 1999.

Ukoli, F. M. A. On the life history, growth and development from the metacercarial stage to adult hood of Clinostomum tilapiae. J. Helminthol., 40, no. 1, p. 215-226, 1966. Available from: <http://dx.doi.org/10.1017/ S0022149X00034209>. Accessed in: Oct. 15, 2015.

Ukoli, F. M. A. On Clinostomum tilapiae n. sp. and Clinostomum phalacrocoracis Dubois, 1931, from Ghana and a discussion of the systematics of the genus Clinostomum Leidy, 
1956. Journal of Helminthology, 40, p. 187-

214, 1966.

Woo, P. T. K. Fish diseases and disorders.

Wallingford: CAB International, 1995. (v. 1,

Protozoan and metazoan infections).

License information: This is an open-access article distributed under the terms of the Creative Commons Attribution License, which permits unrestricted use, distribution, and reproduction in any medium, provided the original work is properly cited.

Braz. J. Biol. Sci., 2016, v. 3, no. 5, p. 97-103. 